\title{
Commentary: (1) Spare the valve; (2) sacrifice the valve; or (3) park valve rudiments in situ, as growable inventory, for future re-employment
}

\author{
David P. Bichell, MD
}

\author{
From the Department of Cardiac Surgery, Monroe Carell, Jr Children's Hospital, Vanderbilt University Medical \\ Center, Nashville, Tenn. \\ Disclosures: Author has nothing to disclose with regard to commercial support. \\ Received for publication July 16, 2019; accepted for publication July 17, 2019; available ahead of print Aug 22, \\ 2019. \\ Address for reprints: David P. Bichell, MD, Pediatric Cardiac Surgery, Monroe Carell, Jr Children's Hospital, \\ Vanderbilt University Medical Center, 5247 Doctors' Office Tower, 2200 Children's Way, Nashville, TN \\ 37232-9292 (E-mail: david.bichell@vanderbilt.edu). \\ J Thorac Cardiovasc Surg 2020;159:2393-4 \\ $0022-5223 / \$ 36.00$ \\ Copyright (C) 2019 Published by Elsevier Inc. on behalf of The American Association for Thoracic Surgery \\ https://doi.org/10.1016/j.jtcvs.2019.07.039
}

Event-free survival and freedom from reoperation are advantages when the pulmonary valve is competent after the repair of tetralogy of Fallot. ${ }^{1,2}$ Expecting $<50 \%$ freedom from reintervention 5 years after pulmonary valve replacement, bioprosthetic valve replacement options for infants and young children are famously limited. ${ }^{3}$ Tissue engineering holds promise as a growing valve, but with human data unavailable, what might be already good news for sheep remains science fiction for mankind. ${ }^{4}$

Ideas for retooling dysplastic pulmonary valves, coaxing growth and competence from rudimentary leaflets, include splitting then augmenting the diminutive anterior leaflet and annulus, ${ }^{5}$ leaflet delamination from the arterial wall, ${ }^{6}$ partial leaflet replacement with a monocusp, ${ }^{7}$ and intraoperative balloon dilation that aims to potentiate annular growth and valve competence. ${ }^{8}$ In the pursuit of coaxing utility out of dysplastic valves, the cure can turn worse than the disease if valve competence comes at the cost of early or late stenosis, insufficiency, and reintervention. Late outcomes do not consistently support a complex salvage operations at primary repair. ${ }^{9}$ Intraoperative balloon annular dilation does not do much to preserve pulmonary valve function, results in ventricular enlargement equivalent to those with transannular patch, and possibly elevates risk for reintervention. ${ }^{8}$ The alchemy of retooling a dysplastic valve has yielded inconsistent results, few guidelines exist to determine which valves are worth the effort, and little guidance to predict which efforts might turn into detriment in the competition of risk between insufficiency and stenosis.

In this issue, Adamson and colleagues show that patients who present late after transannular patch repair with an indexed pulmonary leaflet area $>0.7$ to 0.9 show promise for a durable secondary valve repair. ${ }^{10}$ Recognizing the value of

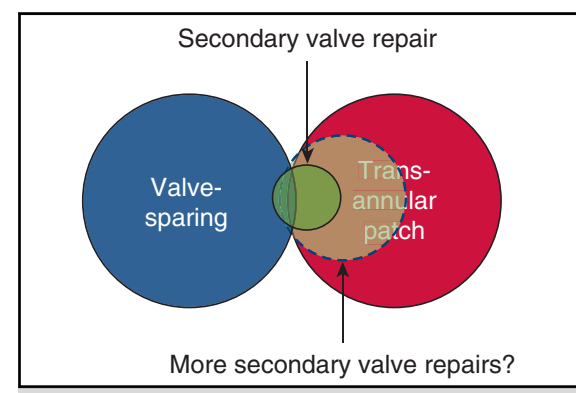

Secondary valve repair (green) can follow transannular primary repair (red).

Central Message

Reconstitution of a functional pulmonary valve after a transannular repair is feasible for some. Whether more leaflets suitable for secondary repair can be cultivated by a thoughtful primary repair remains an open question.

See Article page 2383. living valve tissue and the importance of a full relief of stenosis at primary repair, the authors posit a third concept beyond the binary choice to either rehabilitate or abandon a bad valve at primary repair. A careful, leaflet-sparing transannular patch at primary repair to fully alleviate stenosis, but preserving rudimentary leaflets intact as in situ, growable inventory on the sidelines, can set up a planned future secondary native valve reconstitution. ${ }^{11}$ If nonfunctional leaflets can be parked on the side and can successfully grow over time, an elimination of the original transannular patch at secondary operation reunites now larger leaflets that are capable of competent function without stenosis.

Can the surgeon, as the authors suggest, "set up" at primary repair for a valve that can be reemployed secondarily, or will that option be relegated to a lucky few irrespective of early planning? Important unanswered questions surround the ability at primary repair to encourage meaningful growth of leaflets despite their inaction on the sidelines. Careful patient selection for valve salvage yields best results, but also might restrict the applicability for secondary repair to those with milder dysplasia, rendering success a triumph of low expectations. Cultivating secondary success by choices at the primary repair remains an enticing 
challenge, and it is so far unproven whether such approach can increase a likely small pool of secondary successes.

\section{References}

1. Lindberg HL, Saatvedt K, Seem E, Hoel T, Birkeland S. Single-center 50 years' experience with surgical management of tetralogy of Fallot. Eur J Cardiothorac Surg. 2011;40:538-42.

2. Luijten LWG, van den Bosch E, Duppen N, Tanke R, Roos-Hesselink J, Nijveld A, et al. Long-term outcomes of transatrial-transpulmonary repair of tetralogy of Fallot. Eur J Cardiothorac Surg. 2015;47:527-34.

3. Huygens SA, Rutten-van Mölken MPMH, Noruzi A, Etnel JRG, Corro Ramos I, Bouten CVC, et al. What is the potential of tissue-engineered pulmonary valves in children? Ann Thorac Surg. 2019;107:1845-53.

4. Kluin J, Talacua H, Smits AI, Emmert MY, Brugmans MC, Fioretta ES, et al. In situ heart valve tissue engineering using a bioresorbable elastomeric implant from material design to 12 months follow-up in sheep. Biomaterials. 2017; 125:101-17.

5. Sung SC, Kim S, Woo JS, Lee YS. Pulmonic valve annular enlargement with valve repair in tetralogy of Fallot. Ann Thorac Surg. 2003;75:303-5.
6. Vida VL, Guariento A, Zucchetta F, Padalino M, Castaldi B, Milanesi O, et al. Preservation of the pulmonary valve during early repair of tetralogy of Fallot: surgical techniques. Semin Thorac Cardiovasc Surg Pediatr Card Surg Annu. 2016;19:75-81.

7. Quintessenza JA. Tetralogy of Fallot: management of the pulmonary valve. In: Surgery of Conotruncal Anomalies. Cham, Switzerland: Springer International Publishing; 2016. 139-47.

8. Hofferberth SC, Nathan M, Marx GR, Lu M, Sleeper LA, Marshall AC, et al. Valve-sparing repair with intraoperative balloon dilation in tetralogy of Fallot: midterm results and therapeutic implications. J Thorac Cardiovasc Surg. 2018; 155:1163-73.e1164.

9. Kaza AK, Lim HG, DiBardino DJ, Bautista-Hernandez V, Robinson J, Allan C, et al. Long-term results of right ventricular outflow tract reconstruction in neonatal cardiac surgery: options and outcomes. J Thorac Cardiovasc Surg. 2009;138:911-6.

10. Adamson GT, McElhinney DB, Lui G, Meadows AK, Rigdon J, Hanley FL, et al. Secondary repair of incompetent pulmonary valves after prior surgery or intervention: patient selection and outcomes. J Thorac Cardiovasc Surg. 2020; 159:2383-92.e2.

11. Parry AJ, McElhinney DB, Kung GC, Reddy VM, Brook MM, Hanley FL. Elective primary repair of acyanotic tetralogy of Fallot in early infancy: overall outcome and impact on the pulmonary valve. J Am Coll Cardiol. 2000;36:2279-83. 